\title{
Characterization of five-year observation data of fine particulate matter in the metropolitan area of Lahore
}

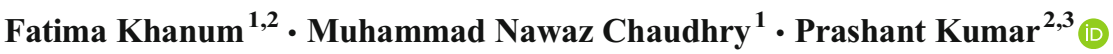

Received: 1 November 2016 / Accepted: 7 February 2017 /Published online: 14 March 2017

(C) The Author(s) 2017. This article is published with open access at Springerlink.com

\begin{abstract}
This study aims to assess the long-term trend of fine particles $\left(\mathrm{PM}_{2.5} ; \leq 2.5 \mu \mathrm{m}\right)$ at two urban sites of Lahore during 2007-2011. These sites represent two distinct areas: commercial (Townhall) and residential cum industrial (Township). The highest daily mean concentrations of $\mathrm{PM}_{2.5}$ were noted as 389 and $354 \mathrm{\mu g} \mathrm{m}^{-3}$ at the Townhall and Township sites, respectively. As expected, the annual seasonal mean of $\mathrm{PM}_{2.5}$ was about 53 and $101 \%$ higher during winter compared with the summer and monsoon/post-monsoon seasons, respectively. On contrary to many observations seen in developing cities, the annual mean $\mathrm{PM}_{2.5}$ during the weekends was higher than weekdays at both monitoring sites. For example, these were 100 (142) and $142 \mu \mathrm{g} \mathrm{m}^{-3}$ (148) during the weekdays (weekends) at the Townhall and Township sites, respectively.
\end{abstract}

Research highlights

- Daily mean $\mathrm{PM}_{2.5}$ at studied sites exceeded national standards and WHO guidelines.

- $\mathrm{PM}_{2.5}$ on weekdays was lesser than weekends due to increased outside city visitors.

- $\mathrm{PM}_{2.5}$ was usually higher by up to $53.5 \%$ in winter compared with summer season.

- $\mathrm{PM}_{2.5}$ showed positive correlations with $\mathrm{NO}_{x}, \mathrm{SO}_{2}$ and $\mathrm{CO}$ while negative with $\mathrm{O}_{3}$.

- Relative difference of $\mathrm{PM}_{10}$ was higher during summer and winter than $\mathrm{PM}_{2.5}$.

\section{Prashant Kumar}

P.Kumar@surrey.ac.uk; Prashant.Kumar@cantab.net

1 College of Earth and Environmental Sciences, The University of Punjab, Lahore, Pakistan

2 Department of Civil and Environmental Engineering, Faculty of Engineering and Physical Sciences, University of Surrey, Guildford GU2 7XH, UK

3 Environmental Flow (EnFlo) Research Centre, Faculty of Engineering and Physical Sciences, University of Surrey, Guildford GU2 7XH, UK
The regression analysis showed a significant positive correlation of $\mathrm{PM}_{2.5}$ with $\mathrm{SO}_{2}, \mathrm{NO}_{2}$ and $\mathrm{CO}$ as opposed to a negative correlation with $\mathrm{O}_{3}$. The bivariate polar plots suggested a much higher influence of localized sources (e.g., road vehicles) at the Townhall site as opposed to industrial sources affecting the concentrations at the Township site. The imageries from the MODIS Aqua/Terra indicated long-range transport of $\mathrm{PM}_{2.5}$ from India to Pakistan during February to October whereas from Pakistan to India during November to January. This study provides important results in the form of multiscale relationship of $\mathrm{PM}_{2.5}$ with its sources and precursors, which are important to assess the effectiveness of pollution control mitigation strategies in Lahore and similar cities elsewhere.

Keywords Fine particles · Air quality monitoring ·

Meteorological parameters $\cdot$ Criteria pollutants $\cdot$ Health risk

\section{Introduction}

Lahore is a metropolitan area with high levels of particulate pollution that often surpasses the guideline values of World Health Organization (WHO) and the National Ambient Air Quality Standards (NAAQS) of Pakistan (Pak-EPA 2005). Both fine and coarse particulate matter cause various types of health concerns (e.g., Stone et al. 2010; Kim et al. 2011; Tsiouri et al. 2015; Lan et al. 2016). The WHO estimated $\sim 360,000$ premature deaths in Asia each year due to air pollution (WHO 2008). The environmental degradation, including water and soil, is about $6 \%$ of Pakistan's GDP, and the indoor and outdoor air pollution contributes nearly half of it towards the total illness and premature mortality (World Bank 2006). The lack of stringent implementation of air pollution regulations and the mass transportation system contribute 
further to the issue of local air pollution (Biswas et al. 2008). Needless to mention that the particulate matter (PM) also plays an important role in affecting the global climate (IPCC 2007; Karagulian et al. 2015).

The increasing population and urbanization have led to an increase in numerous industrial sources as well as the road vehicles (Biswas et al. 2008; Stone et al. 2010; Shah et al. 2012; Rasheed et al. 2015; Ali et al. 2015; Molina et al. 2017). New evidence related to exposure risk assessment and global exposure estimates shows that the exposure to the ambient PM has increased than previously estimated (WHO 2014a). In megacities such as Lahore, important factors for the increased exposure to air pollution are the higher intensity of human activities and emissions from the road vehicles. PM is currently considered to be one of the best indicators for assessing health impacts caused by the ambient air pollution (WHO 2014a; Yao et al. 2015).

Air pollution control in Pakistan has not yet become an electoral issue due to a lack of adequate information for decision and policy makers (Shah et al. 2012), although some sporadic reports recognize airborne PM as a serious environmental and health concern in urban areas of Pakistan (Colbeck et al. 2010; Pak-EPA 2005). As summarized in Table 1, previous studies of ambient air quality in Lahore have documented 24-h averaged maximum $\mathrm{PM}_{2.5}$ during winter season as $200 \mathrm{\mu g} \mathrm{m}^{-3}$ (Biswas et al. 2008), springtime $\mathrm{PM}_{10}$ as $460 \mathrm{\mu g} \mathrm{m}^{-3}$ (Zhang et al. 2008a) and total suspended PM well above $900 \mu \mathrm{g} \mathrm{m}^{-3}$ (Ghauri et al. 2007).

The distribution and transport of PM in the atmospheric environments are markedly associated with meteorological parameters such as the wind speed, wind direction, relative humidity (RH), rainfall and ambient temperature (Pakbin et al. 2010). Therefore, PM concentrations and meteorological data should be evaluated statistically in order to develop correlations that can assist in identifying sources and thereby in the design of cost-effective emission control strategies (Ragosta et al. 2008). The data of ambient air quality are crucial in air resource management but are largely unavailable for rapidly growing cities of Pakistan. The analysis of a 5 -year long-term data set provides significant insight into the factors that drive seasonal variations in PM, their relationship with meteorological parameters and criteria pollutants. This work could be used as an incentive to initiate other studies on trend analysis. It is also anticipated that the findings of this study would be of high relevance for designing and instituting future abatement strategies and emission regulations for the pollution control in rapidly developing cities such as Lahore.

The objective of this paper is to assess the long-term trend of fine particles $\mathrm{PM}_{2.5}$ at two different urban sites of Lahore (Pakistan) between 2007 and 2011. The trend of $\mathrm{PM}_{2.5}$ is compared with Pakistan National NAAQS and WHO guidelines. The seasonal changes in $\mathrm{PM}_{2.5}$ and their underlining reasons during weekdays and weekends, together with the correlation of $\mathrm{PM}_{2.5}$ with other pollutants and meteorological parameters, were also assessed. The AERONET data, backward trajectory and MODIS imageries were used to analyse the long-range transportation of PM and its seasonal contribution. The overall aim of these analyses is to form a basis for the development of appropriate regulatory strategies for limiting the exposure to ambient PM.

\section{Methodology}

\section{Site description}

Lahore $\left(31.320^{\circ} \mathrm{N} ; 74.220^{\circ} \mathrm{E}\right)$ is the second most populated metropolitan area in Pakistan. The population of Lahore is approximately 9.44 million. There are $\sim 3.9$ million motor vehicles and 2150 registered industries in the city (Bureau of Statistics 2015). The major industries in Lahore include the manufacturing of motor cars, motorcycles, steel, chemicals, pharmaceuticals, engineering products and construction materials. The aerosols over the sampling sites derive mainly from soil, road dust and industrial and vehicular emissions. Other anthropogenic sources include emissions from main highways, coal combustion and biomass burning (Biswas et al. 2008). Fixed-site ambient air quality monitoring stations are installed at two different urban locations of Lahore, namely Townhall and Township. Townhall represents a commercial area while the Township is representative of residential cum industrial areas, as shown in Fig. 1.

\section{Instrumentation}

The hourly air quality monitoring data for 5 years between 2007 and 2011 were collected from the Environmental Protection Agency, Punjab (Lahore). Both ambient air quality monitoring stations were equipped with a number of instruments (i.e., combined wind vane, anemometer, thermohydrometer, solar radiation meter) to measure the metrological parameters and air pollutants, as summarized in Table 2. The routine checks of the instrument were carried out for their smooth operation on a weekly, monthly and annual basis to control the quality of the data. There were some gaps in the data due to power failure and routine maintenance (Table 2).

\section{Observation data and analysis}

A data management and reporting software (IDA-ZRW) by HORIBA was used to collect and manage the data at both the ambient air quality monitoring stations. The statistical techniques such as Stata 3, R (Studio) and remote sensing tools such as AERONET were used further for the development of 
Table 1 Summary of the past selected PM studies carried out in Pakistan

\begin{tabular}{|c|c|c|c|c|}
\hline Location & PM types & $\begin{array}{l}\text { Concentration } \\
\left(\mu \mathrm{g} \mathrm{m}^{-3}\right)\end{array}$ & Time span & Reference \\
\hline Lahore (roadside monitoring) & $\mathrm{PM}_{10}$ & 895 & 5-10 April 2001 & Pak-EPA (2005) \\
\hline Lahore (roadside monitoring) & $\begin{array}{l}\mathrm{TSP} \\
\mathrm{PM}_{10}\end{array}$ & $\begin{array}{l}996 \\
368\end{array}$ & 2003-2004 & Ghauri et al. (2007) \\
\hline $\begin{array}{l}\text { Lahore (Pakistan Upper Atmospheric } \\
\text { Research Commission Office) }\end{array}$ & $\mathrm{PM}_{2.5}$ & 209 & $\begin{array}{l}\text { December } 2005 \text { to February } \\
2006\end{array}$ & Biswas et al. (2008) \\
\hline $\begin{array}{l}\text { Lahore (University of Engineering } \\
\text { and Technology, Lahore, UET) }\end{array}$ & $\mathrm{PM}_{10}, \mathrm{OC}, \mathrm{EC}$ & 459 & February to March 2006 & Zhang et al. (2008) \\
\hline $\begin{array}{l}\text { Lahore (Campus Bridge, Punjab } \\
\text { University and Thokar Niaz Baig } \\
\text { Chowk) }\end{array}$ & $\begin{array}{l}\mathrm{PM}_{10} \\
\mathrm{PM}_{2.5} \mathrm{PM}_{1} \\
\mathrm{PM}_{10-2.5}\end{array}$ & $\begin{array}{l}\text { Average } \\
286 \\
222 \\
210 \\
340\end{array}$ & November 2007 & Ali et al. (2015) \\
\hline Lahore (UET) & $\begin{array}{l}\mathrm{PM}_{10} \\
\mathrm{PM}_{2.5}\end{array}$ & Elemental analysis & $2007-2008$ & $\begin{array}{l}\text { Schneidemesser et al. } \\
\quad(2010)\end{array}$ \\
\hline Lahore (Township) & $\begin{array}{l}\mathrm{PM}_{2.5} \text { Metrological } \\
\text { Parameter }\end{array}$ & $\begin{array}{l}\text { Annual average } \\
72.7 \pm 55.2\end{array}$ & $2007-2008$ & Rasheed et al. (2015) \\
\hline Lahore (UET) & $\begin{array}{l}\mathrm{PM}_{10} \\
\mathrm{PM}_{2.5}\end{array}$ & Elemental analysis & $2007-2008$ & Stone et al. (2010) \\
\hline $\begin{array}{l}\text { Lahore (19 different residential } \\
\text { and commercial sites) }\end{array}$ & $\mathrm{PM}_{10}$ & 115 & June to August 2012 & Ashraf et al. (2013) \\
\hline $\begin{array}{l}\text { Lahore (UET Kala Shah Kaku site, } \\
\text { UET Campus site and Lahore } \\
\text { University of Management and } \\
\text { Sciences) }\end{array}$ & $\begin{array}{l}\mathrm{PM}_{10} \\
\text { Aerosol optical depth } \\
\quad(\mathrm{AOD})\end{array}$ & $\begin{array}{l}300 \\
\text { AOD } 0.56-0.67\end{array}$ & 2014-2015 & Khokhar et al. (2016) \\
\hline
\end{tabular}

correlation of $\mathrm{PM}_{2.5}$ with meteorological and pollutant parameters. $\mathrm{PM}_{2.5}$ during weekdays and weekends and across 5 years was calculated, along with the exceedance factor, box plots, wind rose and bivariate polar plots. The satellite imageries from MODIS, backward trajectory and almucantar inversion were used to extract further data on the $\mathrm{PM}_{2.5}$ among different seasons, their sources and dispersion conditions. The almucantar inversion finds the minimum size intervals of PM from 0.439 to $0.992 \mu \mathrm{m}$ (Dubuisson et al. 1996). This minimum size interval is used as a separation point among fine and coarse particles. It also estimates the effective radius, volume median radius, standard deviation and volume concentrations for both fine and coarse particles.

We estimated the annual exceedance factor (EF), and the percent decreases in $\mathrm{PM}_{2.5}$ were estimated to understand the exceedances over the regulatory limits. The annual EF was calculated by using Eq. (1):

Annual EF $=\frac{\text { Observed annual mean } \mathrm{PM}_{2.5} \text { concentration }}{\text { Standard annual mean } \mathrm{PM}_{2.5} \text { concentration }}$

The air quality was categorized into four levels with respect to EF (i) critical pollution when EF $>1.5$, (ii) high pollution when EF is between 1.0 and 1.5, (iii) moderate pollution when EF is between 0.5 and 1.0 and (iv) low pollution when EF $<0.5$ (Kumar et al. 2014). The percent increase in daily and annual mean $\mathrm{PM}_{2.5}$ with respect to $\mathrm{WHO}$ guidelines is estimated using Eqs. (2) and (3):

Daily increase in $\mathrm{PM}_{2.5}$ concentrations (\%)

$=\frac{\left(\text { Observed daily mean } \mathrm{PM}_{2.5}-\text { Standard daily mean } \mathrm{PM}_{2.5}\right)}{\text { Standard daily mean } \mathrm{PM}_{2.5}} \times 100$

Annual increase in $\mathrm{PM}_{2.5}$ concentrations (\%)

$$
=\frac{\left(\text { Observed annual mean } \mathrm{PM}_{2.5}-\text { Standard annual mean } \mathrm{PM}_{2.5}\right)}{\text { Standard annual mean } \mathrm{PM}_{2.5}} \times 100
$$

\section{Results and discussion}

\section{Temporal trend of $\mathbf{P M}_{2.5}$}

Figure $2 \mathrm{a}$ shows the temporal trend of $\mathrm{PM}_{2.5}$ at both the sites between 2007 and 2011. The highest daily average concentration of $\mathrm{PM}_{2.5}$ was nearly the same at both sites, being 384 and $344 \mathrm{~g} \mathrm{~m} \mathrm{~m}^{-3}$ at the Townhall (16 May 2009) and Township (16 November 2007) sites, respectively (Fig. 2a). The annual average $\mathrm{PM}_{2.5}$ over the study duration at Townhall and 


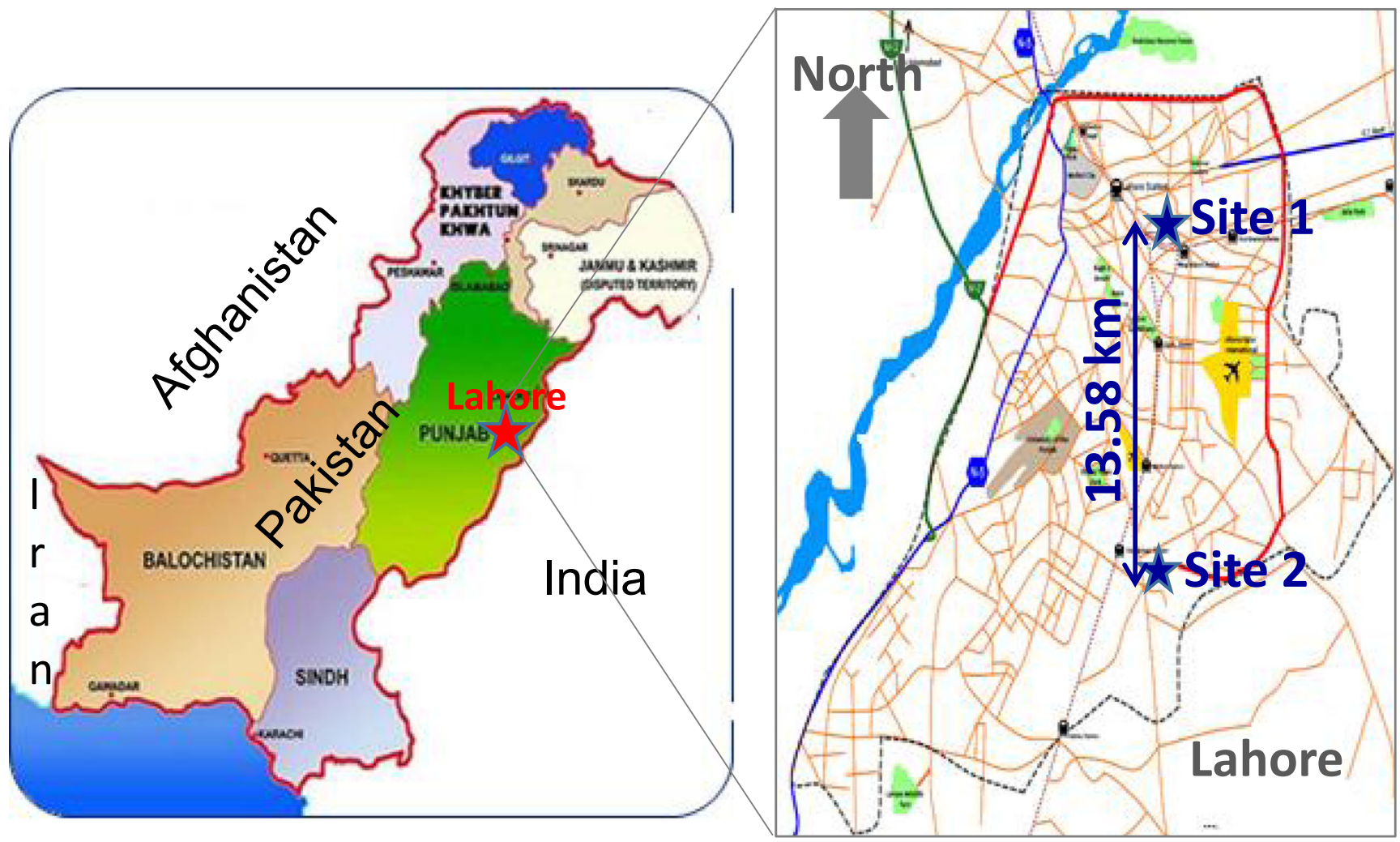

Fig. 1 Location of ambient air quality monitoring sites: Townhall (Site 1) and Township (Site 2)

Township was about $93 \pm 23$ and $180 \pm 45 \mu \mathrm{g} \mathrm{m}^{-3}$, respectively. The annual average $\mathrm{PM}_{2.5}$ of both sides was $136 \pm 34 \mu \mathrm{g} \mathrm{m}^{-3}$. Box plot presents the annual maximum, minimum and mean variation in $\mathrm{PM}_{2.5}$ during the study period (Fig. 2b). The annual mean of $\mathrm{PM}_{2.5}$ did not show an increasing trend over the years (Fig. 2b). One of the reasons is that the concentrations of $\mathrm{PM}_{2.5}$ were affected oddly by the local sources at Townhall site. For example, there was a construction activity of Metro transit system in Lahore during 2009 when the annual mean was noted to the highest. However, annual mean $\mathrm{PM}_{2.5}$ showed increasing concentrations with the time at the Township site, mainly because the sources contributing to $\mathrm{PM}_{2.5}$ were mainly stationary (industrial activities) that increased with the passage of time in this area.

The average minimum $\mathrm{PM}_{2.5}$ was $52 \mu \mathrm{g} \mathrm{m}^{-3}$ at Townhall in 2010 while the average maximum $\mathrm{PM}_{2.5}$ was $280 \mu \mathrm{g} \mathrm{m}^{-3}$ at Township in 2009. These concentrations were much higher than those observed in the European cities but near to $\mathrm{PM}_{2.5}$ found in Asian countries. For example, Ashraf et al. (2013) reported average annual $\mathrm{PM}_{2.5}$ in the capital (Islamabad) of
Table 2 Summary of instrument used for the measurements

\begin{tabular}{|c|c|c|c|c|c|}
\hline $\begin{array}{l}\text { Name of the } \\
\text { instrument }\end{array}$ & Pollutant & Model & Method & $\begin{array}{l}\text { Detection } \\
\text { limit }\end{array}$ & $\begin{array}{l}\text { Fraction of } \\
\text { data available }\end{array}$ \\
\hline $\mathrm{CO}$ monitor & $\mathrm{CO}$ & $\begin{array}{l}\text { Horiba Ltd. } \\
\text { Model } \\
\text { APNA-370 }\end{array}$ & $\begin{array}{l}\text { Nondispersive infrared ray } \\
\text { method (ISO4224) }\end{array}$ & $0.1 \mathrm{ppm}$ & 55 \\
\hline $\mathrm{NO}_{x}$ monitor & $\begin{array}{l}\mathrm{NO}_{x}, \\
\mathrm{NO}, \\
\mathrm{NO}_{2}\end{array}$ & $\begin{array}{l}\text { Horiba Ltd. } \\
\text { Model } \\
\text { APNA-370 }\end{array}$ & $\begin{array}{l}\text { Chemiluminescence } \\
\text { (ISO7996) }\end{array}$ & $0.5 \mathrm{ppb}$ & 50 \\
\hline $\mathrm{SO}_{2}$ monitor & $\mathrm{SO}_{2}$ & $\begin{array}{l}\text { Horiba Ltd. } \\
\text { Model } \\
\text { APSA-370 }\end{array}$ & $\begin{array}{l}\text { UV fluorescence method } \\
\text { (ISO10498) }\end{array}$ & $1 \mathrm{ppb}$ & 51 \\
\hline $\begin{array}{l}\text { Ozone } \\
\text { monitor }\end{array}$ & $\mathrm{O}_{3}$ & $\begin{array}{l}\text { Horiba Ltd. } \\
\text { Model } \\
\text { APOA-370 }\end{array}$ & UV photometry method & $0.5 \mathrm{ppb}$ & 50 \\
\hline Dust analyser & $\mathrm{PM}_{2.5}$ & $\begin{array}{l}\text { Horiba Ltd. } \\
\text { Model } \\
\text { APDA-370 }\end{array}$ & $\begin{array}{l}\beta \text {-Ray absorption method } \\
\quad \text { (ISO6349) }\end{array}$ & $0-5 \mathrm{ppm}$ & 40 \\
\hline
\end{tabular}



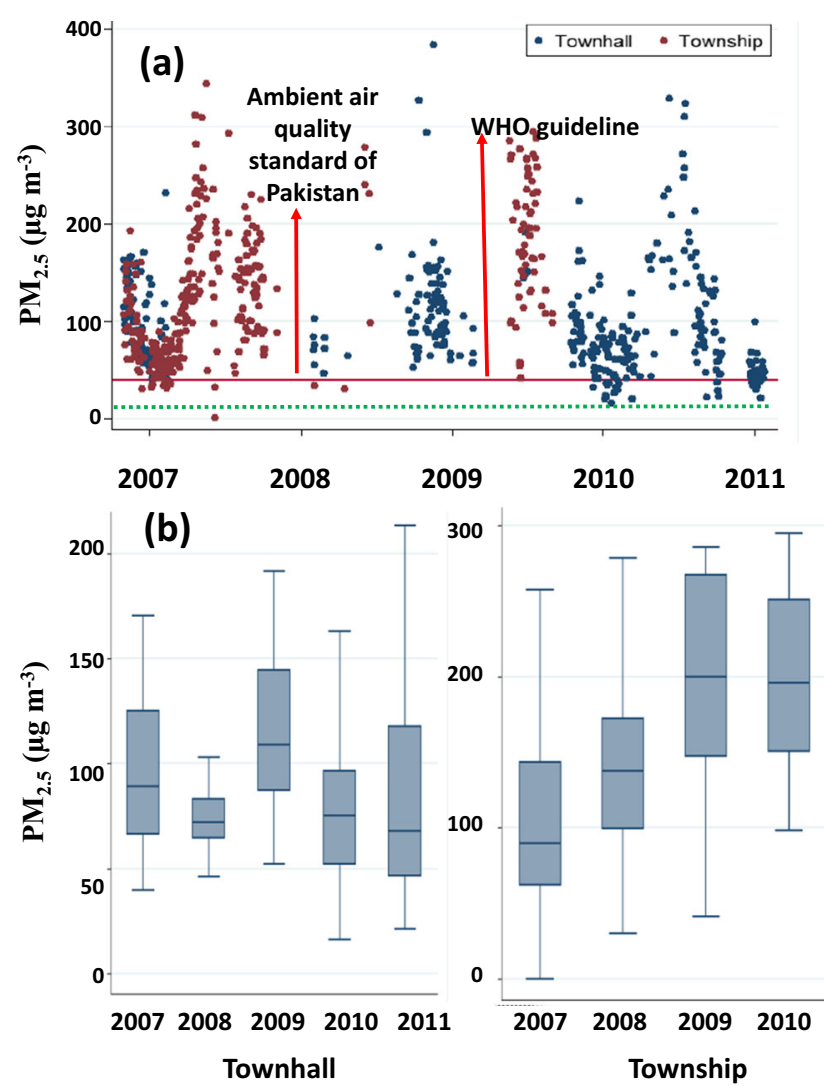

Fig. 2 The trend of a daily and $\mathbf{b}$ annual means of $\mathrm{PM}_{2.5}$ at the studied sites in Lahore

Pakistan as $81.1 \pm 48.4$ and $93.0 \pm 49.9 \mu \mathrm{g} \mathrm{m}^{-3}$ during $2007-$ 2011 , respectively. The similar case can be seen for the annual average concentration in the five most polluted megacities-Delhi (143.0 \pm 17.8$)$, Cairo $(109.6 \pm 27.7)$, Xi'an $(102.2 \pm 9.3)$, Tianjin $(95.7 \pm 7.7)$ and Chengdu $\left(89.4 \pm 14.4 \mu \mathrm{g} \mathrm{m}^{-3}\right)$. Four of these most polluted cities in Asia in terms of $\mathrm{PM}_{2.5}$ were in Asia whereas only Cairo was in Africa. The five least polluted megacities in terms of $\mathrm{PM}_{2.5}$ were Miami (6.7), Toronto $(8.4 \pm 0.3)$, New York $(9.1 \pm 1.0)$, Madrid $(9.9 \pm 1.3)$ and Philadelphia $\left(10.3 \pm 1.0 \mu \mathrm{g} \mathrm{m}^{-3}\right)$; among them, four were in USA and Canada and one (Madrid) in Europe (Cheng et al. 2016). The average annual $\mathrm{PM}_{2.5}$ of both sides of Lahore was $136.5 \pm 34.1 \mu \mathrm{g} \mathrm{m}^{-3}$, which is clearly many fold higher than the USA and European cities and only comparable to Delhi with $143.0 \pm 17.8 \mathrm{\mu g} \mathrm{m}^{-3}$. Table 1 presents the summary of the past relevant PM studies carried out in Pakistan. In general, $\mathrm{PM}_{2.5}$ and $\mathrm{PM}_{10}$ are many times higher than the WHO guidelines and NAAQS permissible limits. Schneidemesser et al. (2010) reported high levels of annual mean $\mathrm{PM}_{10}$ $340 \mathrm{\mu g} \mathrm{m}^{-3}$ for Lahore during 2007. Likewise, Stone et al. (2010) showed a maximum $\mathrm{PM}_{10}$ concentration of $650 \mathrm{\mu g} \mathrm{m}^{-3}$ on a typical polluted day during 2007. As for different seasons, the average $\mathrm{PM}_{2.5}$ during winter was $\sim 157$ and $171 \mu^{-3} \mathrm{~g}^{-3}$ at Townhall and Township sites, respectively, followed by the corresponding values of $~ 99$ and $115 \mu \mathrm{g} \mathrm{m}^{-3}$ during summer and $\sim 66$ and $97 \mu \mathrm{g} \mathrm{m}^{-3}$ during monsoon/post-monsoon (Fig. 3a). Winter, summer and monsoon/post-monsoon months were taken as NovemberFebruary, March-June and July-October, respectively. The lowest $\mathrm{PM}_{2.5}$ was observed during monsoon/post-monsoon due to heavy precipitation as opposed to the highest $\mathrm{PM}_{2.5}$ during winter due to low inversion and stable atmospheric stability condition (Tiwari et al. 2013). The average concentration during the winter was about $53 \%$ higher than those during summer and almost double than those during the monsoon/post-monsoon. Similar seasonal trends were reported by Tiwari et al. (2013) in Delhi with daily mean $\mathrm{PM}_{2.5}$ in winter as $150.8 \mu \mathrm{g} \mathrm{m}^{-3}, 70.9 \mu \mathrm{g} \mathrm{m}^{-3}$ during summer and $45.1 \mathrm{\mu g} \mathrm{m}^{-3}$ during monsoon.

The daily mean concentration of $\mathrm{PM}_{2.5}$ during weekends (Saturday-Sunday) was relatively higher than the weekdays (Monday-Friday) at both monitoring sites of Lahore. This is an interesting finding, which is opposite to many cities worldwide where much lower concentrations are usually reported during the weekends (Al-Dabbous and Kumar 2014; Yadav et al. 2014). For examples, the mean $\mathrm{PM}_{2.5}$ during the weekdays at the Townhall sites was measured as $95 \mu \mathrm{g} \mathrm{m}^{-3}$ as opposed to $100 \mu \mathrm{g} \mathrm{m}^{-3}$ during the weekends; the corresponding values were 142 and $148 \mathrm{\mu g} \mathrm{m}^{-3}$ at the Township site, respectively (Fig. 3b). The predominant reason for this interesting trend is that a relatively higher number of people living in surrounding suburban/rural areas visit Lahore for recreational purposes during the weekends, which is a typical feature of many Asian cities that result in increased traffic volume and in turn the $\mathrm{PM}_{2.5}$.
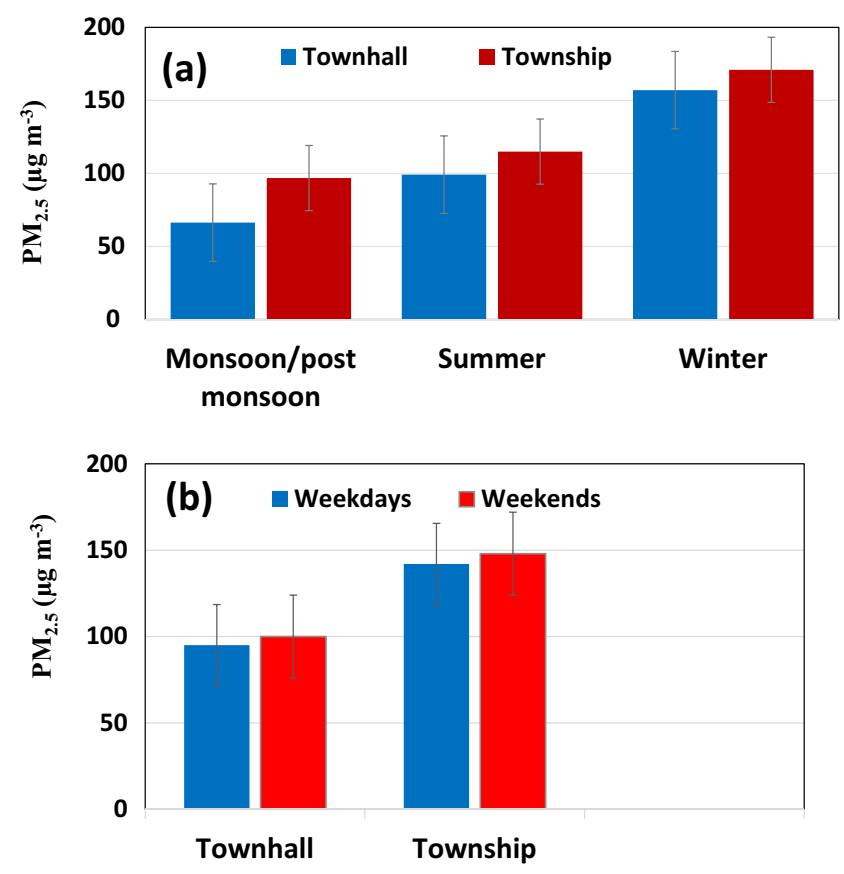

Fig. 3 a Seasonal and b weekly trends of $\mathrm{PM}_{2.5}$ at the studied sites 
Fig. 4 Annual exceedance factor as per WHO guideline $(\mathbf{a}, \mathbf{b})$ as per NAAQS of Pakistan $(\mathbf{c}, \mathbf{d})$ annual percentage increase $(\mathbf{e}, \mathbf{f})$ and daily percentage increase (g, h) as per WHO guidelines of $\mathrm{PM}_{2.5}$ at the studied sites in Lahore
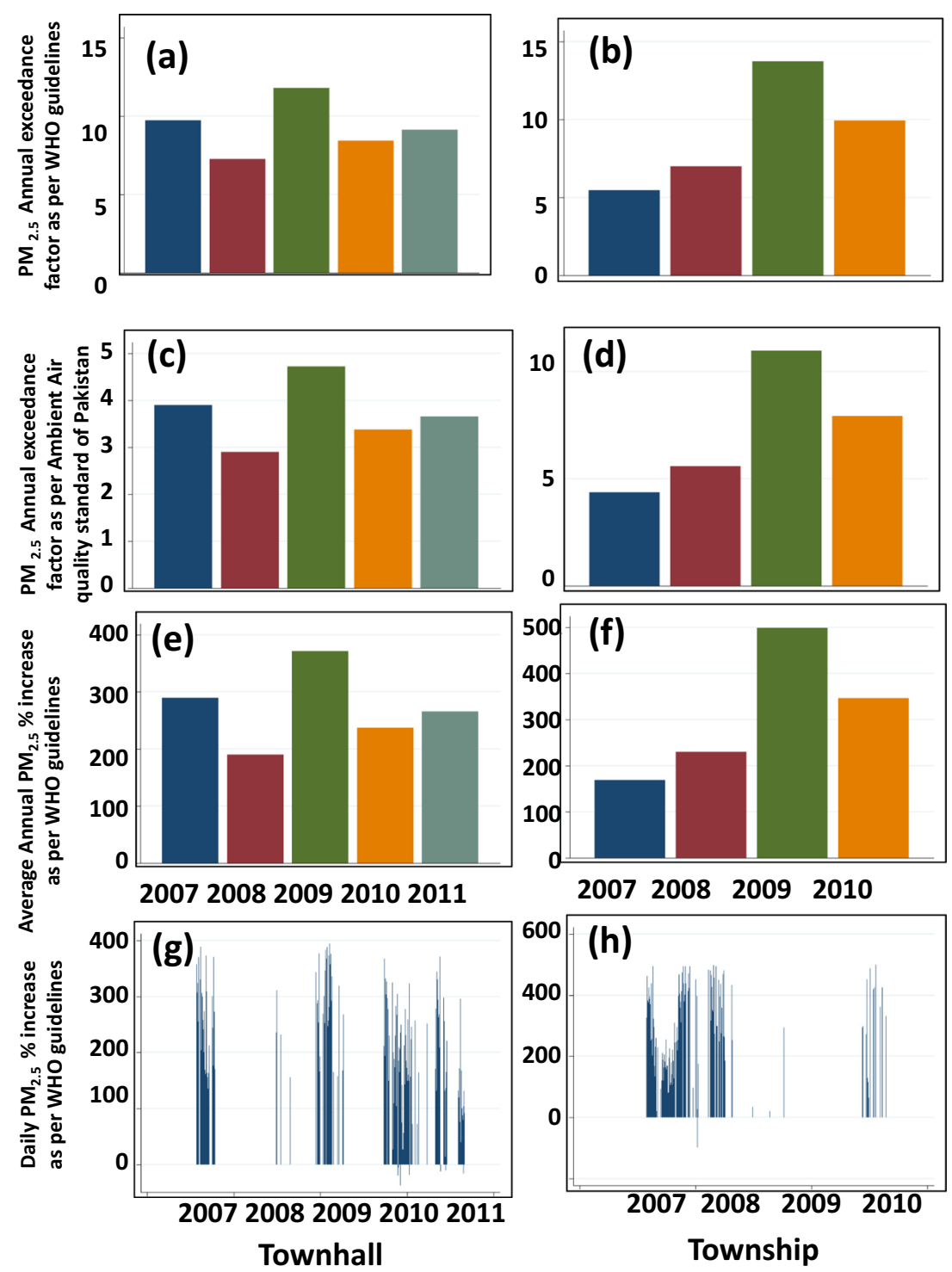

\section{Annual exceedances}

The status of noncompliance at both sides of Lahore was measured by using annual EF, as described in "Observation data and analysis" section. The EFs for Townhall and Township with respect to WHO guidelines and NAAQS (Pakistan) lie within the range of 6-14 and 3-12, respectively (Fig. 4d). The result indicates the alarmingly high levels of $\mathrm{PM}_{2.5}$ on both sites of Lahore and categorizes them above critical pollution level (Kumar et al. 2014). The values for daily and annual percentage increases lie within the range of $100-500$ and $180-500 \%$, respectively (Fig. 4e-h). This shows that the noncompliance of $\mathrm{PM}_{2.5}$ with respect to WHO guidelines was mostly about $100-500 \%$ above on daily and annual basis, respectively. The sub-zero values in Fig. 4g, h represent the days when $\mathrm{PM}_{2.5}$ was less than the WHO guidelines.
Primary emissions of $\mathrm{PM}_{10}$ and $\mathrm{PM}_{2.5}$ decreased by 14 and $16 \%$, respectively, in the EU-27 in 2011 compared with 2002 2011 levels (Ikeda and Tanimoto 2015). The reductions in the same period for the 32 member countries of the European Union were 9\% for $\mathrm{PM}_{10}$ and $16 \%$ for $\mathrm{PM}_{2.5}$, respectively (Ikeda and Tanimoto 2015). In a WHO study, a total of 795 towns/cities from 67 countries were selected; 641 cities represent the high-income countries and 55 represent the middleand low-income countries with available data of $\mathrm{PM}_{10} / \mathrm{PM}_{2.5}$ from 2008 to 2013. It was found that globally PM levels were increased by about $8 \%$. The $90 \%$ of the low- and middleincome cities assessed exceeded annual WHO guidelines for $\mathrm{PM}_{10}$ and $\mathrm{PM}_{2.5}$. The worldwide future trends in $\mathrm{PM}_{10}$ and $\mathrm{PM}_{25}$ concentrations show a decrease in $30 \%$ of the regions as opposed to modest or increasing trend in the remaining $70 \%$ of the regions (WHO 2016). This study clear falls within the 
Fig. 5 Annual bivariate polar plots for $\mathrm{PM}_{2.5}$ at both sites in Lahore
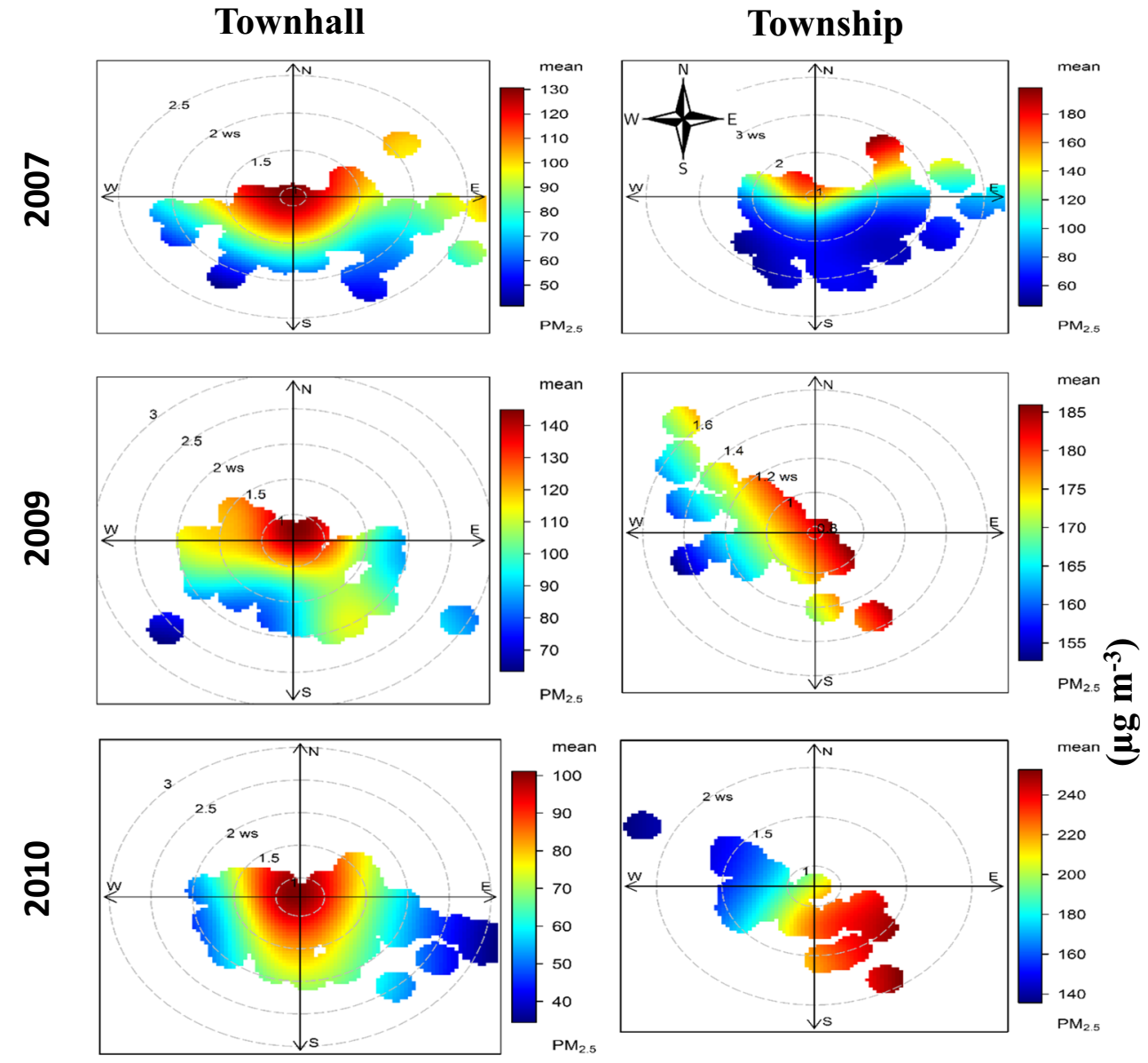

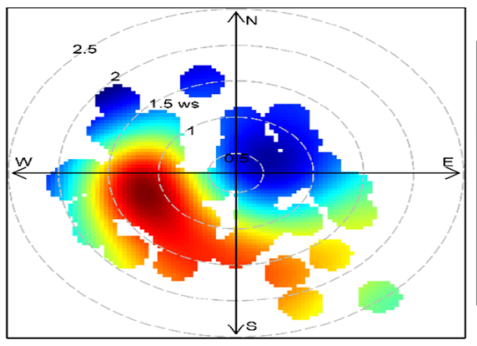

2011

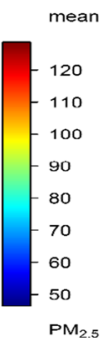

$\mathrm{PM}_{2.5}$

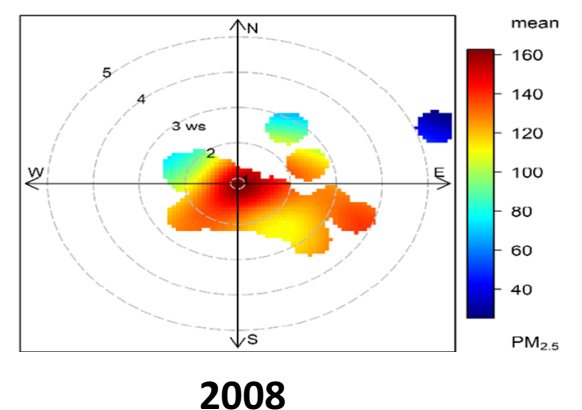

rest of 70\% regions with increasing $\mathrm{PM}_{2.5}$ concentrations as is also the case with the most cities in developing countries (WHO 2016). The annual exceedances at the selected sites of Lahore were between 100 and $500 \%$ (Fig. 4e-h), indicating much higher concentrations compared with those reported in studies of European or high-income countries elsewhere (Ikeda and Tanimoto 2015; WHO 2016).

\section{Bivariate polar plots}

Figures 5 and 6 show the bivariate polar plots for the annual and seasonal annual average $\mathrm{PM}_{2.5}$ concentrations for both the sites, respectively. A variation in concentrations, depending on the local wind direction and wind speed at the sampling locations, is clearly evident (Figs. 5 and 6). The similar methods of representing the air quality data have been adopted by past studies while assessing the long-term $\mathrm{PM}_{2.5}$ data (Azarmi et al. 2016; Mouzourides et al. 2015).

The colour scale of bivariate polar plots of $\mathrm{PM}_{2.5}$ shows the concentration, and the radial scale shows the wind speed. The concentration increases from the centre of the plot radially outwards in some cases while an opposite trend is seen in other cases. Bivariate polar plots of Townhall indicate that $\mathrm{PM}_{2.5}$ sources were mostly localized as depicted by high concentrations in the centre at low wind speeds, mainly contributed by the emissions from road vehicles (Fig. 5). A slight shift towards the southwest direction in monsoon/postmonsoon season at the Townhall was due to increased 
Fig. 6 Bivariate polar rose plots for $\mathrm{PM}_{2.5}$ during different seasons at both sites in Lahore
Townhall Wind Rose

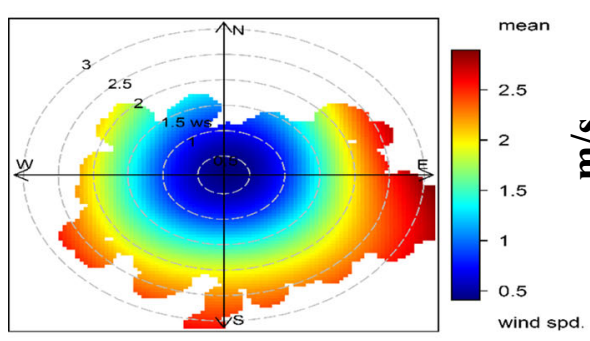

\section{Seasonal Bivariate Polar Plots}

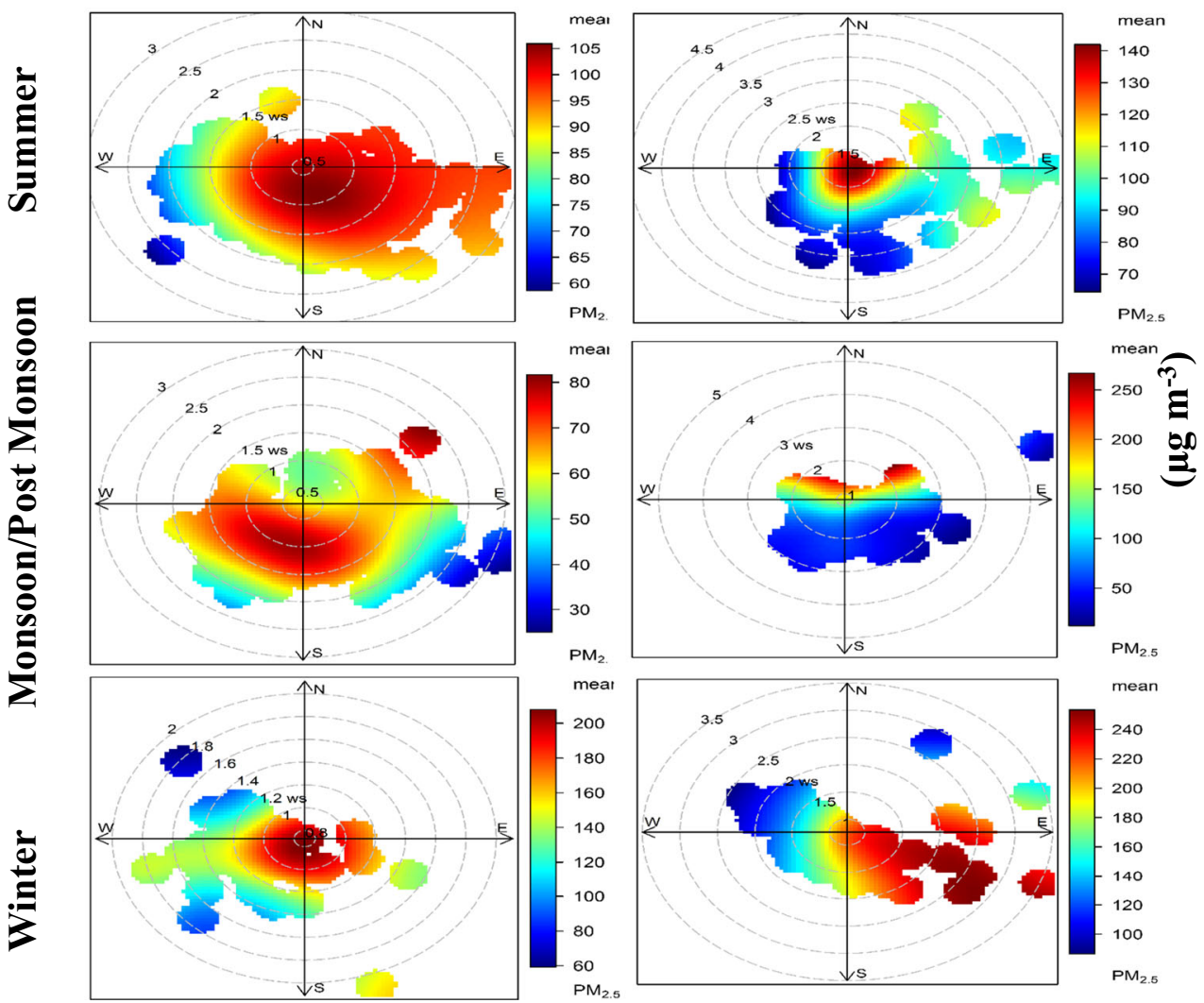

precipitation (Fig. 6). The annual bivariate polar plot of Townhall in 2011 showed a shift towards southwest due to intense construction activity of a $27-\mathrm{km}$-long bus rapid transit system in Lahore (Fig. 5); both the annual and seasonal bivariate polar plots for the Township indicate transport of $\mathrm{PM}_{2.5}$ to the site from the presence of industrial areas in the east and southeast direction of air monitoring station (Figs. 5 and 6).

\section{Correlation of $\mathbf{P M}_{2.5}$ with the criteria pollutant and meteorological parameters}

Regression analysis was used to assess the correlation between $\mathrm{PM}_{2.5}$ and $\mathrm{NO}_{2}, \mathrm{CO}, \mathrm{O}_{3}$ and $\mathrm{SO}_{2}$ (Fig. 7a-d). The positive correlation was found among $\mathrm{NO}_{2}, \mathrm{CO}, \mathrm{SO}_{2}$ and
$\mathrm{PM}_{2.5}$ with $95 \%$ confidence interval. Diesel combustions from heavy duty vehicles, electricity generators and industrial emissions were considered to be a major source of both $\mathrm{CO}, \mathrm{SO}_{2}$ and $\mathrm{NO}_{2}$. The association between $\mathrm{CO}, \mathrm{SO}_{2}, \mathrm{NO}_{2}$ and $\mathrm{PM}_{2.5}$ was significantly positive, suggesting that they were contributing to the production of $\mathrm{PM}_{2.5}$. On the other hand, a negative correlation of $\mathrm{PM}_{2.5}$ with $\mathrm{O}_{3}$ suggests that $\mathrm{O}_{3}$ was increased when $\mathrm{PM}_{2.5}$ was decreased. Previous studies (Ashraf et al. 2013; Rasheed et al. 2015) reported the similar correlations among $\mathrm{PM}_{2.5}$ and $\mathrm{NO}_{x}, \mathrm{CO}, \mathrm{O}_{3}$ and $\mathrm{SO}_{2}$ in different cities of Pakistan, indicating the consistency of our results with the past observations.

The correlations among the significant meteorological parameters such as wind speed, ambient temperature, $\mathrm{RH}$ and 
Fig. 7 Correlation of $\mathrm{PM}_{2.5}$ with $\mathrm{CO}, \mathrm{NO}_{2}, \mathrm{SO}_{2}$ and $\mathrm{O}_{3}(\mathbf{a}-\mathbf{d})$ and with wind speed, temperature and relative humidity (e-h) during the studied period at Townhall
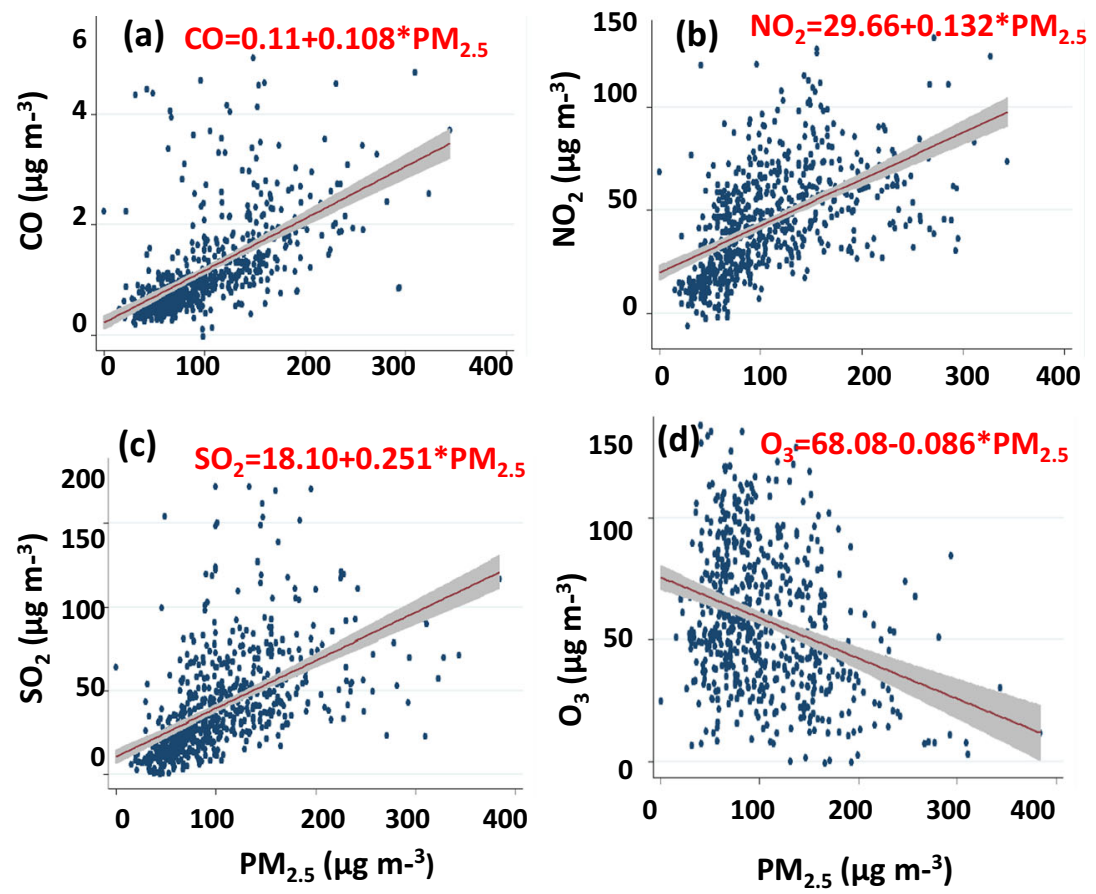

(e)

(f)

(g)

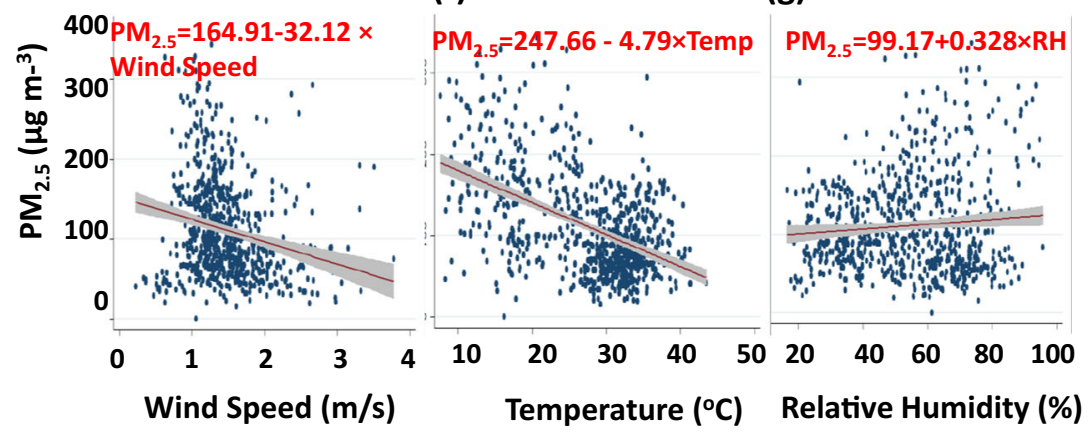

$\mathrm{PM}_{2.5}$ show a negative correlation with temperature (Fig. 7e) and wind speed (Fig. 7f) and no correlations with the RH (Fig. 7g). This demonstrates the fact why $\mathrm{PM}_{2.5}$ concentrations were much higher in winter than in summer (Fig. 3a) due to a decrease in temperature and wind speed. Such higher levels raise a number of concerns including reduced visibility affecting the speed of on-road vehicles and the increased cases of both chronic and acute respiratory and cardiovascular health problems in the region, as discussed by previous studies (Tiwari et al. 2013; Yin et al. 2016).

\section{MODIS fires hotspots and the effect of transboundary pollution}

The MODIS Aqua/Terra imagery data were used for the identification of pollution hotspot in the study area during the summer and winter seasons (Fig. 8). The red spots indicate the major sources of air pollution. The predominant winds of Lahore come from west and northwest in the winter season whereas from the southeast during the summer and post-monsoon seasons (Fig. 6). MODIS Terra/ Aqua imageries in summer and winter seasons of Lahore were used to assess the trans-boundary movement of air pollution. The transport of air pollution during November to February was not so significant because the average mean wind speed during these months was $\sim 1.5 \mathrm{~m} / \mathrm{s}$ compared with $\sim 3.5 \mathrm{~m} / \mathrm{s}$ between March and October. A recent study by Rasheed et al. (2015) included the back-trajectory analysis of four major cities of Pakistan and reported that the air masses originating from western India were from the states of Gujrat, Rajasthan and Punjab with sources generating $\mathrm{PM}_{2.5}$ such as coal-fired power plants, industries and vehicular emissions, which contribute to air pollution of Lahore (Singh and Kaskaoutis 2014; Rasheed et al. 2015). In addition, wheat harvesting during MarchApril and dry winter climatic conditions also play an important role in elevated $\mathrm{PM}_{2.5}$ values during the months of October-November in Lahore. 


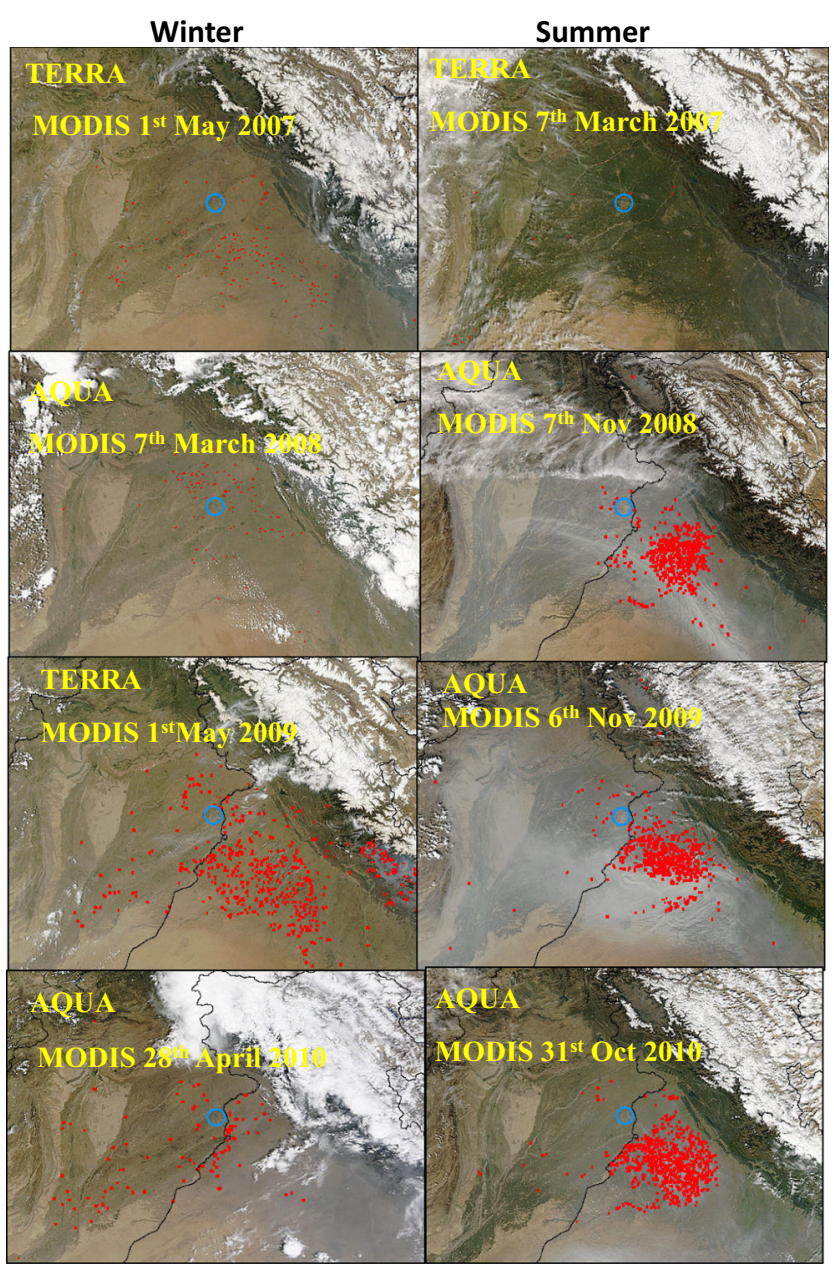

Fig. 8 MODIS Terra/Aqua imageries in summer and winter seasons of Lahore

\section{Size distribution of aerosol particles}

The almucantar inversion aerosol optical property retrieved from AERONET data was used to find out the relative particulate size difference of fine and coarse particles during winter and summer seasons of Lahore during the study period (Fig. 9). The relative difference in $\mathrm{PM}_{10}$ was much higher in summer than winter. The similar results were reported by Ali et al. (2013) on the size distribution of coarse particles in Lahore. They found $\mathrm{PM}_{10}$ to be three times higher in summer than in winter and fall seasons. However, fine mode particles did not show any substantial difference in concentration during all the four seasons. A similar trend was observed by Dey et al. (2004) while analysing the effect of dust storms on seasonal optical properties of the Indo-Gangetic region. The increased wind speed caused gale and wind storms during summer, besides an increase in the relative difference of $\mathrm{PM}_{10}$ among winter and summer seasons. The AERONET almucantar inversion data present the substantial relative difference in $\mathrm{PM}_{10}$ whereas the marginal substantial difference in $\mathrm{PM}_{2.5}$ of winter and summer seasons, opposed to a relative difference of ground-based data of $\mathrm{PM}_{2.5}$ as shown in Fig. 3a.

\section{Summary and conclusions}

We assessed the temporal trend of fine PM $\left(\mathrm{PM}_{2.5}\right)$ over a period of 5 years in Lahore. The annual mean $\mathrm{PM}_{2.5}$ concentrations were found to be increasing at Township site and show no clear trend at the Townhall site during the study period. Our findings show that the levels of $\mathrm{PM}_{2.5}$ reach to their highest levels during the winter season. For example, the highest daily mean $\mathrm{PM}_{2.5}$ measure at Townhall and Township was found to be 389 and $354 \mu \mathrm{g} \mathrm{m}^{-3}$, respectively.

The annual average minimum $\mathrm{PM}_{2.5}$ was found to be $52 \mu \mathrm{g} \mathrm{m}^{-3}$ at Townhall during 2010 while the average maximum $\mathrm{PM}_{2.5}$ was $280 \mu \mathrm{g} \mathrm{m}^{-3}$ at Township during 2009. $\mathrm{PM}_{2.5}$ crossed $98 \%$ daily and $100 \%$ annual permissible limits of NAAQS and WHO guidelines at both sites of Lahore. The average concentrations during the winter were found to be about 53\% higher than those during summer and almost double than the monsoon/post monsoon, mainly due to a decrease in temperature and stagnant climatic conditions. Seasonal air quality trend of Lahore from 2007 to 2011 was analysed and found that the highest annual mean $\mathrm{PM}_{2.5}$ in winter was 157 $171 \mathrm{\mu g} \mathrm{m}^{-3}$, summer 99-115 $\mathrm{\mu g} \mathrm{m}^{-3}$ and monsoon/postmonsoon 66-97 $\mathrm{\mu g} \mathrm{m}^{-3}$ at Townhall and Township, respectively.

$\mathrm{PM}_{2.5}$ during weekdays was usually less by up to $4 \%$ than weekends. The annual EF of $\mathrm{PM}_{2.5}$ with respect to WHO guidelines lies within the range of 3-14 and 6-12 with respect to NAAQS of Pakistan at Townhall and Township sites, respectively. The daily and annual $\%$ increases lie in the range of $100-500 \%$ with respect to $\mathrm{WHO}$ guidelines at both monitoring sites of Lahore.

The sources contributing to $\mathrm{PM}_{2.5}$ at the Townhall site were mostly localized as opposed to Township where there is the influence of transported emissions from the adjacent industrial sites. Correlation of $\mathrm{PM}_{2.5}$ with $\mathrm{CO}, \mathrm{NO}_{2}$ and $\mathrm{SO}_{2}$ was positive and negative with $\mathrm{O}_{3}$. However, the correlation of $\mathrm{PM}_{2.5}$ with meteorological parameters such as temperature and wind speed was negative and nonsignificant with RH. Retrieved MODIS Aqua/Terra imageries, together with predominant wind direction, showed the influence of transboundary air pollution from India towards Lahore during the months of March to October as opposed to an opposite trend during the months of November to February when the long-range transport of $\mathrm{PM}_{2.5}$ is from Lahore to India.

This study contributes to understanding the long-term trend of $\mathrm{PM}_{2.5}$ in the urban environment of Lahore. Our findings are important to understanding the surrounding sources and 
Fig. 9 Relative particle size distribution in winter and summer seasons of Lahore

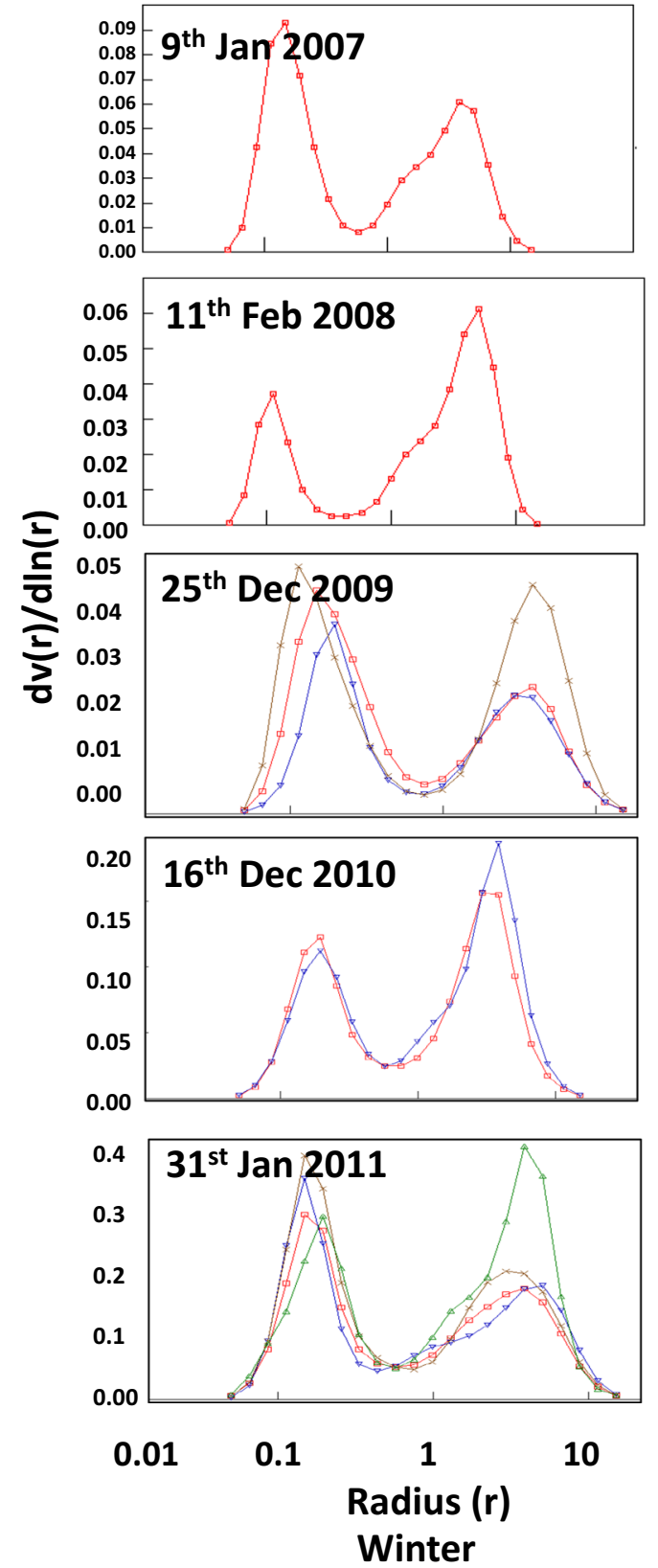

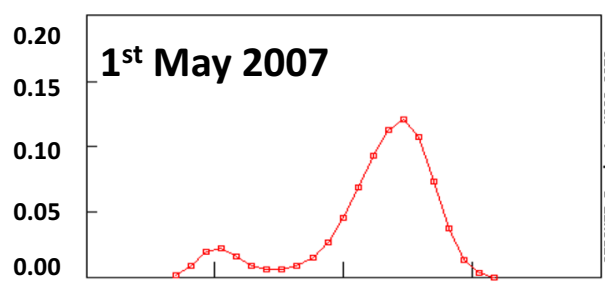

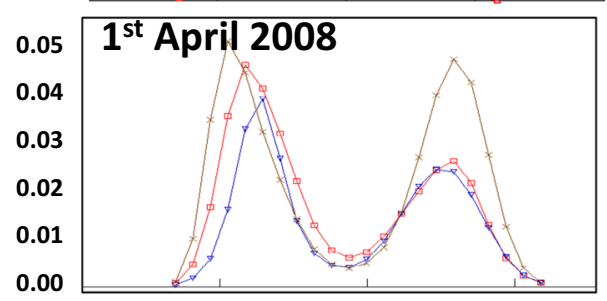

0.00
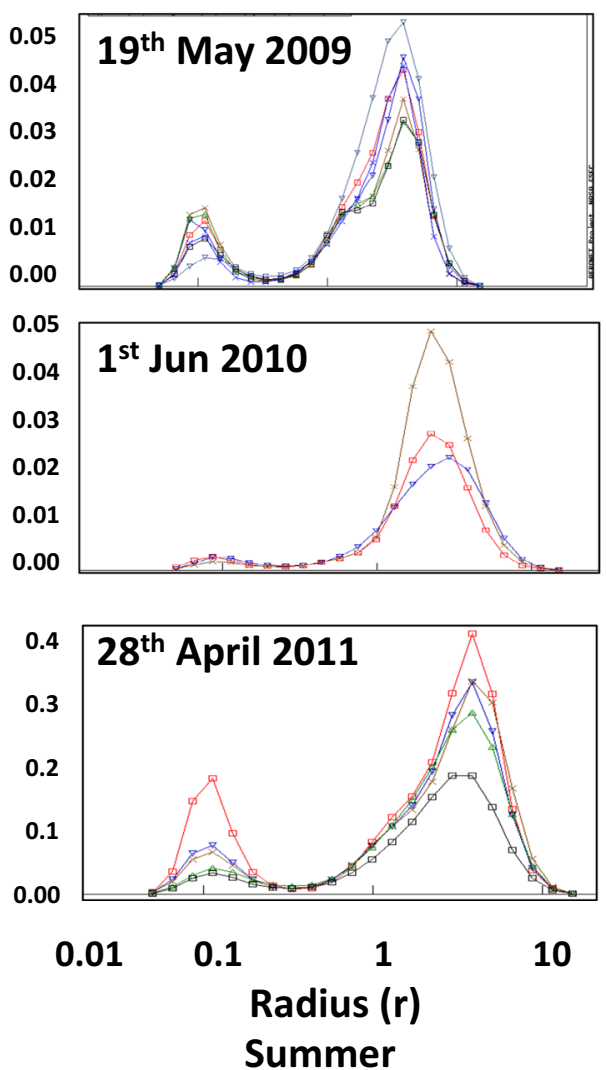

underline the factors that bring the seasonal variability in $\mathrm{PM}_{2.5}$. Further studies require the monitoring at a greater number of sites to broaden the understanding of spatial variability across the city along with a physicochemical analysis of the fine particles.

Acknowledgements The authors are grateful to the Higher Education Commission (Pakistan) and the Environmental Protection Agency, Punjab (Lahore), for the funding support to Fatima Khanum that enabled us to carry out this research work. We also thank Mr. Farooq Alam (research officer, Air Pollution Lab at the EPA), Mr. Toshiharu Ochi (JICA expert) and Mr. Hassan Murtaza Khan (statistical analyst) for their valuable suggestions and contributions to this work.
Open Access This article is distributed under the terms of the Creative Commons Attribution 4.0 International License (http:// creativecommons.org/licenses/by/4.0/), which permits unrestricted use, distribution, and reproduction in any medium, provided you give appropriate credit to the original author(s) and the source, provide a link to the Creative Commons license, and indicate if changes were made.

\section{References}

Al-Dabbous AN, Kumar P (2014) Number size distribution of airborne nanoparticles during summertime in Kuwait: first observations from the Middle East. Env Sci Tech 48:13634-13643 
Ali M, Tariq S, Mahmood K, Daud A, Batool A, Haq Z (2013) A study of aerosol properties over Lahore (Pakistan) by using AERONET data Asia-Pacific. Asia-Pac J Atmos Sci 50:153-162

Ali Z, Rauf A, Sidra S, Nasir ZA, Colbeck I (2015) Air quality (particulate matter) at heavy traffic sites in Lahore, Pakistan. J Anim Plant Sci 25:644-648

Ashraf N, Mushtaq M, Sultana B, Iqbal M, Ullah I, Shahid AS (2013) Preliminary monitoring of tropospheric air quality of Lahore City in Pakistan. Int J Chem Biochem Sci 3:19-28

Azarmi F, Kumar P, Marsh D, Fuller G (2016) Assessment of the longterm impacts of $\mathrm{PM}_{10}$ and $\mathrm{PM}_{2.5}$ particles from construction works on surrounding areas. Environ Sci Process Impacts 18:208-221

Biswas KF, Ghauri BM, Husain L (2008) Gaseous and aerosol pollutants during fog and clear episodes in south Asian urban atmosphere. Atmos Environ 42:7775-7785

Bureau of Statistics (2015) Punjab development statistics 2015. Government of Punjab, Lahore

Cheng Z, Luo L, Wang S, Wang Y, Sharma S, Shimadera H, Wang BM, Miranda MR, Jiang J, Zhou W, Fajardo O, Yan N, Hao J (2016) Status and characteristics of ambient $\mathrm{PM}_{2.5}$ pollution in global megacities. Environ Int 89:212-221

Colbeck I, Nasir ZA, Ali Z (2010) Characteristics of indoor/outdoor particulate pollution in urban and rural residential environment of Pakistan. Indoor Air 20:40-51

Dey S, Tripathi SN, Singh RP, Holben BN (2004) Influence of dust storms on the aerosol optical properties over the Indo-Gangetic basin. J Geophys Res 109:D20211

Ghauri B, Lodhi A, Mansha M (2007) Development of baseline (air quality) data in Pakistan. Environ Monit Assess 127:237-252

IPCC (2007) Climate Change 2007. Impacts, adaptation and vulnerability: Contribution of Working Group II to the Fourth Assessment Report of the Intergovernmental Panel. Genebra, Suíca (accessed 07.08.2016)

Ikeda K, Tanimoto H (2015) Exceedances of air quality standard level of $\mathrm{PM}_{2.5}$ in Japan caused by Siberian wildfires. Environ Res Lett 10: 105001

Karagulian F, Belis AC, Dora FC, Prüss-Ustün MA, Bonjour S, Rohani AH, Amann M (2015) Contributions to cities ambient particulate matter (PM): a systematic review of local source contributions at global level. Atmos Environ 120:475-483

Khokhar FM, Yasmin N, Chishti F, Shahid I (2016) Temporal variability and characterization of aerosols across the Pakistan region during the winter fog periods. Atmosphere 7:67

Kim NK, Kim YP, Kang CH (2011) Long-term trend of aerosol composition and direct radiative forcing due to aerosols over Gosan TSP, $\mathrm{PM}_{10}$, and $\mathrm{PM}_{2.5}$ data between 1992 and 2008. Atmos Environ 45: $6107-6115$

Kumar S, Srinivas N, Sunil KA (2014) Monitoring and assessment of air quality with reference to dust particles $\left(\mathrm{PM}_{10}\right.$ and $\left.\mathrm{PM}_{2.5}\right)$ in urban environment. Int J Res Eng Tech 3:2321-7308

Lan G, Yuan Z, Maddock JE, Cook A, Chu YY, Pan BB, Tu H, Fan S, Liao X, Lu Y (2016) Public perception of air pollution and health effects in Nanchang, China. Air Qual Atmos Health 9:951-959

Molina C, Toro AR, Morales SRG, Manzano C, Guzmán LAM (2017) Particulate matter in urban areas of south-central Chile exceeds air quality standards. Air Qual Atmos Health 10:1-15

Mouzourides P, Kumar P, Neophytou MKA (2015) Assessment of longterm measurements of particulate matter and gaseous pollutants in south-east Mediterranean. Atmos Environ 107:148-165
Pakbin P, Hudda N, Cheung KL, Moore KF, Sioutas C (2010) Spatial and temporal variability of coarse $\left(\mathrm{PM}_{10-2.5}\right)$ particulate matter concentrations in the Los Angeles area. Aerosol Sci Technol 44:514-525

Pak-EPA (2005) State of the environment report. Pakistan Environmental Protection Agency, Ministry of Environment, Government of Pakistan. Available from: http://environment.gov.pk/state-ofenvironment-report/ 27-6-2016 (accessed 08.07.2016)

Ragosta M, Caggiano R, Macchiato M, Sabia S, Trippetta S (2008) Trace elements in daily collected in a four-year study. Atmos Res 89:206217

Rasheed A, Aneja VP, Aiyyer A, Rafique U (2015) Measurement and analysis of fine particulate matter in urban areas of Pakistan. Aerosol Air Qual Res 15:426-439

Schneidemesser E, Stone EA, Quraishi TA, Shafer MM, Schauer JJ (2010) Toxic metals in the atmosphere in Lahore, Pakistan. Sci Total Environ 408:1640-1648

Shah M, Shaheen N, Nazir R (2012) Assessment of the trace elements level in urban atmospheric particulate matter and source apportionment in Islamabad Pakistan. Atmos Pollut Res 3:39-45

Singh RP, Kaskaoutis DG (2014) Crop residue burning a threat to south Asian air quality. Earth Space Sci 95:333-334

Stone E, Schauer J, Qureshi TA, Mahmood A (2010) Chemical characterization and source apportionment of fine and coarse particulate matter in Lahore, Pakistan. Atmos Environ 44:1062-1070

Tiwari S, Srivastava AK, Bisht DS, Parmita P, Srivastava MK, Attri SD (2013) Diurnal and seasonal variations of black carbon and $\mathrm{PM}_{2.5}$ over New Delhi, India: influence of meteorology. Atmos Res 125: $50-62$

Tsiouri V, Kakosimos K, Kumar P (2015) Concentrations, physicochemical characteristics and exposure risks associated with particulate matter in the Middle East area-a review. Air Qual Atmos Health $8: 67-80$

WHO (2008) Health topics: air. World Health Organization, Regional Office for the Western Pacific. wpro.who.int/health topics/air 4-62016 (accessed 15.07.2016)

WHO (2014) Ambient air quality and health. Fact sheet No 313. WHO media centre. Available at: http://www.who.int/mediacentre/ factsheets/fs313/en 21-5-2016 (accessed 15.07.2016)

WHO (2016) Urban ambient air pollution database, 0.2, Public Health, Social and Environmental Determinants of Health Department, World Health Organization, 1211 Geneva 27, Switzerland. Available at: http://www.who.int/phe/health topics/outdoorair/ databases/cities/en/1-9-2016 (accessed 12.07.2016)

World Bank (2006) Pakistan strategic country environmental assessment, South Asia environment and social development unit south, The World Bank, 36946-PK. Available at:http://siteresources. worldbank.org/SOUTHASIAEXT/Resources/Publications/4488131188777211460/pakceavolume1.pdf 25-5-2016 (accessed 05.06. 2016)

Yadav R, Sahu LK, Jaffrey SNA, Gufran B (2014) Temporal variation of particulate matter and potential sources at an urban site of Udaipur in western India. Aerosol Air Qual Res 14:1613-1629

Yao L, Lu N, Yue X, Du J, Yang X (2015) Comparison of hourly $\mathrm{PM}_{2.5}$ observations between urban and suburban areas in Beijing, China. Int J Environ Res 12:12264-12276

Yin D, Zhao S, Qu J (2016) Spatial and seasonal variations of gaseous and particulate matter pollutants in 31 provincial capital cities, China. Air Qual Atmos Health 10:1-12

Zhang YX, Qureshi T, Schauer JJ (2008) Daily variation in sources of carbonaceous aerosol in Lahore, Pakistan during a high pollution spring episode. Aerosol Air Qual Res 8:130-146 